\title{
TAHAP PRELIMINARY RESEARCH PENGEMBANGAN LKPD BERBASIS PBL UNTUK MATERI MATEMATIKA SEMESTER 1 KELAS VIII SMP
}

\author{
Zulfah \\ Universitas Pahlawan Tuanku Tambusai, Jl. Tuanku Tambusai No.23 Bangkinang \\ Email: zulfahasni670@gmail.com
}

\begin{abstract}
Problem-solving skills as one of the essential capabilities for students, is still not fully achieved yet. There are several factors causing the low ability. One of them is the unavailability of teaching materials which facilitates students to grow and develop mathematical problem solving ability optimally. This study aims to develop Teaching Materials of Students' Worksheets (TMSW) based on Problem Based Learning (PBL) for the first semester of math materials which are valid, practical, and effective.The type of this research is design research. This study uses a Plomp's model that consists of three phases, For the first phase that is preliminary phase of research carried out a needs analysis, analysis of learners, curriculum analysis, analysis of the concept, as well as analysis of existing teaching materials. In the prototype phase, it starts to design TMSW mathematics material based PBL for the first semester, then carried out a formative evaluation to determine the validity and practicality of the product in the form of TMSW based on PBL. The last is assessment phase, this phase is to test the practicalities and effectiveness of assessment. The Effectiveness can be seen through quasi experiment research.
\end{abstract}

Keywords. Problem Based Learning, Student's worksheets, TMSW based on PBL

\begin{abstract}
Abstrak
Kemampuan pemecahan masalah sebagai salah satu kemampuan matematis yang harus dimiliki peserta didik. Ada beberapa factor penyebab rendahnya kemampuan pemecahan masalah. Salah satunya adalah tidak tersedianya bahan ajar yang memudahkan siswa untuk tumbuh dan mengembangkan kemampuan pemecahan masalah matematis secara optimal. Penelitian ini bertujuan untuk mengembangkan Bahan Ajar Lembar Kerja Siswa (TMSW) berdasarkan Problem Based Learning (PBL) untuk semester pertama materi matematika yang valid, praktis, dan efektif. Jenis penelitian ini adalah penelitian desain. Penelitian ini menggunakan model Plomp yang terdiri dari tiga tahap, Untuk tahap pertama yaitu tahap awal penelitian dilakukan analisis kebutuhan, analisis peserta didik, analisis kurikulum, analisis konsep, serta analisis bahan ajar yang ada. Pada tahap prototipe, ia mulai merancang materi matematika berbasis TMSW berbasis PBL untuk semester pertama, kemudian melakukan evaluasi formatif untuk mengetahui validitas dan kepraktisan produk dalam bentuk TMSW berdasarkan PBL. Yang terakhir adalah tahap penilaian, tahap ini adalah untuk menguji kepraktisan dan efektivitas penilaian. Efektivitasnya bisa dilihat melalui eksperimen kuasi.
\end{abstract}

Kata Kunci: Pembelajaran Berbasis masalah, Lembar Kerja Siswa, Lembar Kerja Siswa Berbasis PBL

Ada beberapa macam kemampuan matematis dalam pembelajaran matematika, salah satunya adalah kemampuan pemecahan masalah matematis. Pentingnya memiliki kemampuan pemecahan masalah matematis telah disadari oleh banyak pihak. Sejak Kurikulum 2004, Kurikulum Berbasis Kompetensi (KBK), kemampuan pemecahan masalah matematis telah dijadikan sebagai salah satu tujuan dalam pembelajaran matematika. Kemampuan pemecahan masalah sebagai salah satu tujuan pembelajaran yang esensial dalam pembelajaran matematika di sekolah juga ditetapkan dalam Permendiknas No. 58 tahun 2014. 
Kemampuan pemecahan masalah merupakan kemampuan yang dapat digunakan dalam memperoleh solusi dari suatu permasalahan yang membutuhkan prosedur atau langkah yang tidak rutin dan terdapat dalam suatu bentuk teks, teka-teki non rutin dan situasi-situasi dalam kehidupan nyata. Indikator yang menunjukkan kemampuan pemecahan masalah matematis menurut kurikulum 2013 diantaranya 1) Memahami masalah, 2) Mengorganisasi data dan memilih informasi yang relevan dalam mengidentifikasi masalah, 3) Menyajikan suatu rumusan masalah secara matematis dalam berbagai bentuk, 4) Memilih pendekatan dan strategi yang tepat untuk memecahkan masalah, 5) Menggunakan atau mengembangkan strategi pemecahan masalah, 6) Menafsirkan hasil jawaban yang diperoleh untuk memecahkan masalah, 7) Menyelesaikan masalah[2]. Dari ketujuh indikator yang telah ditetapkan, maka dapat dirangkum menjadi empat indikator kemampuan pemecahan masalah yang diantaranya yaitu 1) Memahami masalah, 2) Merencanakan strategi penyelesaian, 3) Melaksanakan rencana penyelesaian, serta 4) Memeriksa kembali serta menarik kesimpulan. Keempat indikator tersebut dijadikan sebagai acuan dalam menilai kemampuan pemecahan masalah matematis peserta didik.

Kenyataannya, berdasarkan observasi dan wawancara dengan beberapa guru yang berada di SMP N 13 dan SMP N 15 Padang diperoleh gambaran bahwa sebagian besar peserta didik memiliki kemampuan pemecahan masalah matematis yang relatif rendah. Rendahnya kemampuan pemecahan masalah matematis peserta didik terlihat pada saat peserta didik diberikan soal pemecahan masalah, peserta didik tidak dapat menjawab soal tersebut. Pada jawaban peserta didik terlihat bahwa terdapat beberapa indikator yang tidak dapat dicapai oleh peserta didik, diantaranya indikator merancang strategi penyelesaian, melaksanakan strategi penyelesaian, serta menyimpulkan dan memeriksa kembali jawaban yang diperoleh. Salah satu contoh soal pemecahan masalah matematis yang diberikan guru kepada peserta didik dapat dilihat pada Gambar 1.

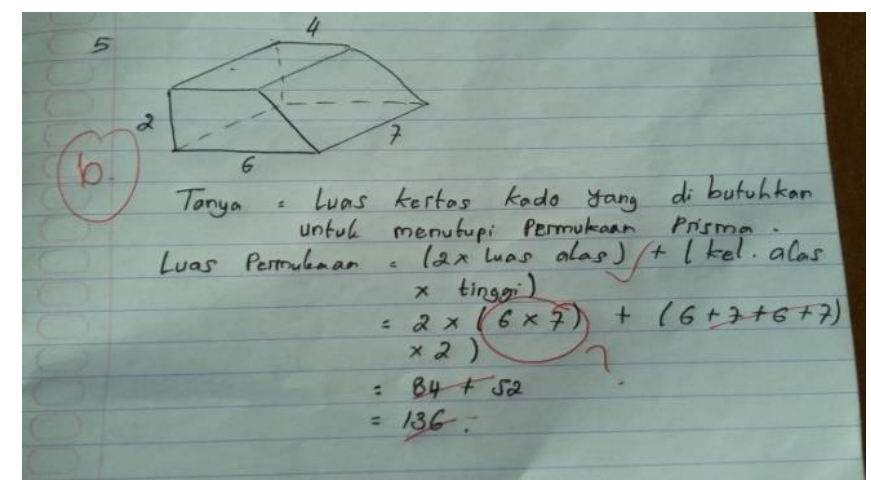

Gambar 1. Contoh Jawaban Peserta Didik

(Sumber: Penelitian Sherlyane Hendri (2015))

Permasalahan mengenai rendahnya kemampuan pemecahan masalah matematis peserta didik ini perlu dicarikan solusi agar tidak ditemukan lagi peserta didik berkemampuan pemecahan masalah 
matematis yang rendah. Cara yang dapat dilakukan adalah dengan melaksanakan perbaikan pada proses pembelajaran. Salah satu penentu keberhasilan proses pembelajaran dan keberhasilan dalam pencapaian tujuan pembelajaran matematika adalah perangkat pembelajaran.

Perangkat pembelajaran merupakan sekumpulan alat atau kompoen yang digunakan dalam proses pembelajaran yang terdiri dari silabus, rencana pelaksanaan pembelajaran (RPP), bahan ajar, dan tes hasil belajar. Satu dari bahan ajar cetak yang digunakan dalam proses pembelajaran di sekolah adalah Lembar Kerja Peserta Didik atau disingkat LKPD. LKPD adalah panduan bagi peserta didik untuk melakukan kegiatan penyelidikan atau pemecahan masalah. LKPD ini dapat berupa panduan untuk mengembangkan aspek kognitif maupun panduan untuk mengembangkan semua aspek pembelajaran. LKPD berbasis $P B L$ merupakan LKPD yang dapat membantu peserta didik menemukan konsep. Pada pembelajaran yang menggunakan LKPD berbasis $P B L$, konsep dapat ditemukan secara mandiri oleh peserta didik. LKPD adalah salah satu bahan ajar cetak yang dapat mempermudah peserta didik untuk berinteraksi dengan materi yang diberikan. LKPD dapat mempermudah guru dalam melaksanakan proses pembelajaran. LKPD juga kaya akan tugas untuk berlatih. Selain itu LKPD juga dapat membantu peserta didik untuk aktif dalam proses pembelajaran karena berisikan aktivitas yang melibatkan peserta didik [4]. Pada sekolah tersebut LKPD dijadikan sebagai alat yang membantu peserta didik dalam mengkonstruksi pengetahuannya.

Banyak usaha yang telah dilakukan pemerintah agar dapat meningkatkan kualitas perangkat pembelajaran. Salah satunya dengan memfasilitasi forum MGMP untuk melakukan penyusunan materi ajar yang serupa dengan LKPD sebagai wadah untuk melatih peserta didik pada saat proses pembelajaran berlangsung. Pada materi ajar yang serupa dengan LKPD tersebut, materi disajikan pada awal proses pembelajaran dan diikuti dengan pemberian soal-soal latihan. Pada materi ajar tersebut juga telah tercantum soal-soal yang dinyatakan sebagai soal-soal pemecahan masalah. Namun, soal yang dinyatakan sebagai soal pemecahan masalah tersebut tidak sesuai dengan kriteria yang harus dimiliki oleh soal pemecahan masalah. Soal pemecahan masalah yang disajikan tidak bersifat kontekstual, rutin, dan tidak bersifat open-ended.

Agar tercapainya tujuan pembelajaran matematika yang salah satunya adalah kemampuan pemecahan masalah matematis, maka perlu diberikan inovasi baru terhadap LKPD yang bertujuan untuk mengkonstruksi pengetahuan peserta didik. Selain itu, LKPD tersebut perlu menyajikan soalsoal pemecahan masalah yang sesuai dengan kriteria dari pemecahan masalah yaitu kontekstual, open-ended dan non-rutin. Selanjutnya peserta didik juga perlu diajarkan langkah-langkah dalam menyelesaikan permasalahan. Hal ini didasarkan atas pendapat Arends yang menyatakan bahwa guru yang menuntut peserta didik untuk memiliki penguasaan kemampuan pemecahan masalah yang artinya dapat menyelesaikan masalah, maka guru tersebut haruslah mengajarkan bagaimana peserta didik seharusnya menyelesaikan masalah.

Inovasi yang dilakukan pada LKPD tersebut yaitu berupa penggunaan suatu model atau strategi pembelajaran yang dijadikan sebagai landasan dalam mengembangkan LKPD. LKPD akan 
semakin optimal jika berlandaskan pada salah satu model atau strategi pembelajaran yang memiliki tujuan untuk meningkatkan kemampuan pemecahan masalah peserta didik dan mengajarkan cara menyelesaikan sebuah permasalahan. Salah satu model/ strategi pembelajaran yang dapat digunakan untuk mencapai tujuan tersebut adalah melalui Problem Based Learning atau disingkat PBL.

Problem Based Learning $(P B L)$ adalah suatu strategi atau model pembelajaran ataupun pendekatan pembelajaran yang menggunakan masalah dunia nyata sebagai suatu konteks atau masalah bagi peserta didik untuk belajar tentang cara berpikir kritis dan keterampilan pemecahan masalah, serta dapat memperoleh pengetahuan dan konsep yang esensial dari materi pelajaran. Jika biasanya proses pembelajaran diawali dengan pemberian materi pelajaran dan barulah dilanjutkan dengan pemberian permasalahan, maka pembelajaran dengan $P B L$ menjadikan pemberian permasalahan sebagai awal dari proses pembelajaran. Melalui penyelesaian permasalahan tersebut maka peserta didik akan diarahkan dan dibimbing untuk mengkonstruksi pengetahuan dari materi yang dipelajari. Strategi atau pendekatan Problem Based Learning ini dapat disajikan pada LKPD.

Permasalahan yang disajikan tersebut bersifat kontekstual, non rutin ataupun open-ended. Permasalahan tersebut akan dicarikan penyelesaiannya melalui rangkaian kegiatan seperti menemukan/ mengidentifikasi masalah, mengumpulkan fakta, menyusun hipotesis, melakukan penyelidikan, dan menyimpulkan alternatif pemecahan masalah. Kegiatan tersebut akan membantu peserta didik untuk bekerja menyelesaikan masalah dalam langkah yang sistematis demi tercapainya penguasaan kemampuan matematis terutama kemampuan pemecahan masalah pada diri peserta didik. Selain itu, tahapan-tahapan yang dilakukan dalam menemukan penyelesaian dari permasalahan juga dapat membimbing dan membantu peserta didik dalam mencapai indikator-indikator yang telah ditetapkan dalam indikator kemampuan pemecahan masalah. Melalui tahapan menemukan dan merumuskan masalah, serta tahapan mengumpulkan data/fakta, dapat melatih peserta didik untuk mengembangkan kemampuan memahami masalahnya yang merupakan indikator pertama dalam kemampuan pemecahan masalah. Pada tahapan selanjutnya, yaitu tahap mengajukan hipotesis dan melakukan penyelidikan, dapat membimbing dan mengarahkan peserta didik untuk mencapai indikator merencanakan sekaligus melaksanakan penyelesaian sebagai indikator kedua dan ketiga dari kemampuan pemecahan masalah, dan yang terakhir tahapan menyimpulkan pemecahan masalah secara kolaboratif dan melakukan pengujian hasil (solusi pemecahan masalah) dapat membimbing peserta didik mencapai indikator kemampuan pemecahan masalah yang keempat yaitu mengambil kesimpulan dan mengevaluasi kembali. Melalui LKPD berbasis $P B L$, diharapkan dapat membantu guru dalam memfasilitasi peserta didik untuk mengembangkan kemampuan pemecahan masalah matematis peserta didk. LKPD yang bercirikan model pembelajaran $P B L$ yang menjadikan permasalahan sebagai starting point juga dapat membuat peserta didik memperoleh pembelajaran yang bermakna, dikarenakan permasalahan yang disajikan berasal dari keseharian peserta didik dan sesuatu yang dapat dibayangkan dan dipikirkan oleh peserta didik. Selain itu LKPD berbasis $P B L$ juga 
dapat meningkatkan kemampuan komunikasi, kerja kelompok dan keterampilan interpersonal peserta didik dengan baik.

\section{METODE}

Pada penelitian ini, model pengembangan yang digunakan diadaptasi dari model yang dikembangkan oleh Plomp. Model Plomp terdiri dari tiga tahap, yaitu tahap analisis pendahuluan, tahap pengembangan atau pembuatan prototipe (Development or Prototyping Phase), dan tahap penilaian (Assessment Phase). Analisis pendahuluan dilaksanakan untuk memperoleh informasi mengenai permasalahan yang terdapat pada dunia pendidikan. Selain itu melalui analisis pendahuluan, peneliti memperoleh gambaran sementara dari produk yang dikembangkan. Pada tahap analisis pendahuluan, dilakukan analisis kebutuhan, analisis peserta didik, analisis kurikulum, analisis konsep, dan analisis bahan ajar yang telah ada.

Analisis kebutuhan dilaksanakan dengan melakukan observasi dan wawancara. Wawancara dilakukan terhadap guru, dan beberapa peserta didik. Informasi yang diambil terkait dengan proses pembelajaran yang berlangsung selama ini, baik dari aspek tercapai atau tidaknya tujuan pembelajaran yang telah ditetapkan dalam kurikulum, deskripsi kegiatan pembelajaran di kelas, dan ada atau tidaknya bahan ajar yang dapat memfasilitasi pengembangan kemampuan pemecahan masalah matematis peserta didik. Analisis peserta didik dilakukan guna menelaah karakteristik dari peserta didik di kelas VIII SMP. Karakteristik yang diperhatikan meliputi level berpikir, dan kecendrungan gaya belajar. Pada tahap ini juga ditanyakan LKPD seperti apa yang diinginkan peserta didik. Analisis ini dijadikan sebagai pertimbangan dalam merancang LKPD berbasis $P B L$.

Analisis kurikulum bertujuan untuk menganalisis dua aspek penunjang yaitu SK dan KD. Pada tahap ini dilakukan telaah terhadap kurikulum KTSP untuk mata pelajaran matematika kelas VIII SMP. Analisis ini dilakukan untuk mempelajari cakupan materi, tujuan pembelajaran, dan materi yang dapat disajikan pada LKPD berbasis $P B L$.

Analisis konsep merupakan identifikasi materi-materi yang dibahas pada pembelajaran. Materi-materi ini disusun secara sistematis dengan mengaitkan suatu konsep dengan konsep lain yang relevan sehingga membentuk suatu konsep. Analisis ini bertujuan untuk menentukan isi dan materi pelajaran yang diperlukan sehingga dapat membantu peserta didik dalam mencapai kompetensi yang diinginkan yaitu kemampuan pemecahan masalah matematis. Analisis konsep dilengkapi dengan pembuatan peta konsep. Pada tahap analisis bahan ajar yang telah ada, dilakukan pengumpulan informasi mengenai bahan ajar yang digunakan oleh guru dalam proses pembelajaran di kelas. Pengumpulan informasi dilakukan melalui observasi, dokumentasi, dan wawancara.

\section{Tabel 1}

\section{Ringkasan Kegiatan Pada Tahap Preliminary Research}




\begin{tabular}{|c|c|}
\hline $\begin{array}{l}\text { Kegiatan } \\
\text { Penelitian }\end{array}$ & Fokus Penelitian \\
\hline $\begin{array}{l}\text { Analisis } \\
\text { Kebutuhan }\end{array}$ & $\begin{array}{l}\text { - Apa tujuan pembelajaran matematika yang terdapat dalam } \\
\text { kurikulum telah tercapai? } \\
\text { - Bagaimanakah proses pembelajaran selama ini? } \\
\text { - Apakah bahan ajar yang digunakan pada proses pembelajaran } \\
\text { dapat mencapai tujuan pembelajara yang telah ditetapkan? }\end{array}$ \\
\hline $\begin{array}{l}\text { Analisis Peserta } \\
\text { Didik }\end{array}$ & $\begin{array}{l}\text { - Bagaimana karakteristik peserta didik kelas VIII SMP terkait } \\
\text { dengan pembelajaran matematika? } \\
\text { - Bahan ajar/ LKPD seperti apa yang diinginkan peserta didik? }\end{array}$ \\
\hline $\begin{array}{l}\text { Analisis } \\
\text { Kurikulum }\end{array}$ & $\begin{array}{l}\text { - Materi (SK, KD) manakah yang dapat disajikan pada LKPD } \\
\text { berbasis } P B L \text { ? } \\
\text { - Apakah materi tersebut sudah memadai untuk mencapai tujuan } \\
\text { kurikulum? Jika belum, apa yang perlu ditambahkan? } \\
\text { - Apakah materi tersebut sudah terurut dengan baik? Jika belum, } \\
\text { bagaimana urutan yang seharusnya? Mengapa demikian? }\end{array}$ \\
\hline Analisis Konsep & $\begin{array}{l}\text { - Konsep-konsep esensial apa saja yang diperlukan untuk } \\
\text { pembelajaran (yang diperoleh berdasarkan analisis kurikulum) } \\
\text { sehingga dapat membantu dalam mencapai kompetensi yang } \\
\text { diinginkan? } \\
\text { - Bagaimana peta konsep dari konsep-konsep tersebut? }\end{array}$ \\
\hline $\begin{array}{l}\text { Analisis Bahan } \\
\text { Ajar yang Telah } \\
\text { Ada }\end{array}$ & $\begin{array}{l}\text { - Inspirasi apa yang dapat diambil dari bahan ajar yang telah ada } \\
\text { saat ini? } \\
\text { - Perubahan dan/atau peningkatan apa yang akan dilakukan untuk } \\
\text { mengatasi kelemahan yang terdapat pada bahan ajar yang telah } \\
\text { tersedia } \\
\text { - Karakteristik apa yang akan ditonjolkan dalam bahan ajar yang } \\
\text { akan dirancang? }\end{array}$ \\
\hline
\end{tabular}

\section{HASIL DAN PEMBAHASAN}

Bagian ini memuat hasil atau data penelitian, analisis data penelitian, jawaban dari pertanyaaan penelitian, dan analisis terhadap temuan selama penelitian.

Analisis pendahuluan dilakukan pada peserta didik kelas VIII SMP Negeri 13 Padang. Hasil dari analisis pendahuluan terbagi menjadi hasil analisis kebutuhan, hasil analisis peserta didik, analisis kurikulum, analisis konsep, serta hasil analisis bahan ajar yang telah ada. 


\section{Hasil Analisis Kebutuhan}

Berdasarkan observasi dan wawancara yang dilakukan di SMP Negeri 13 dan SMP Negeri 15 Padang, diperoleh kesimpulan bahwa salah satu tujuan pembelajaran matematika yang esensial yaitu kemampuan pemecahan masalah matematis masih bersifat rendah. Hal ini disebabkan belum terlaksananya proses pembelajaran yang dapat menumbuh-kembangkan kemampuan pemecahan masalah matematis peserta didik. Selain itu, LKPD yang disediakan di sekolah belum optimal memfasilitasi peserta didik untuk mencapai tujuan pembelajaran terutama kemampuan pemecahan masalah matematis. Belum adanya bahan ajar seperti LKPD yang dikhususkan untuk mengembangkan kemampuan pemecahan masalah matematis peserta didik membuat guru kesusahan dalam mencapai tujuan pembelajaran tersebut. Oleh sebab itu, agar dapat mengasah kemampuan pemecahan masalah matematis peserta didik, guru membutuhkan perangkat pembelajaran yang dapat memfasilitasi peserta didik untuk menumbuh dan mengembangkan kemampuan pemecahan masalah matematisnya.

Salah satu alternatif penyelesaian dari permasalahan tersebut yaitu dengan menyediakan perangkat pembelajaran khususnya bahan ajar berupa LKPD yang dapat menunjang tercapainya tujuan pembelajaran yang diinginkan. LKPD merupakan salah satu bahan ajar cetak yang dapat membantu guru dalam mencapai tujuan pembelajaran terutama untuk meningkatkan kemampuan pemecahan masalah matematis peserta didik. LKPD yang disediakan haruslah didasarkan pada pendekatan pembelajaran yang mengarah kepada student center, serta didasarkan pada suatu kegiatan yang dapat mengembangkan kemampuan pemecahan masalah matematis peserta didik. Salah satu model/ strategi pembelajaran yang dapat memfasilitasi peserta didik untuk mengembangkan kemampuan pemecahan masalahnya adalah Problem Based Learning (PBL).

Melalui LKPD berbasis $P B L$, peserta didik dapat mengasah kemampuan pemecahan masalah matematisnya, dikarenakan $P B L$ merupakan salah satu model/ strategi belajar yang dapat digunakan untuk memfasilitasi peserta didik dalam menumbuhkembangkan kemampuan pemecahan masalah matematisnya. Selain itu LKPD yang dikembangkan harus dapat menarik perhatian peserta didik untuk menggunakannya, karena berdasarkan wawancara yang dilakukan dengan beberapa peserta didik juga dapat disimpulkan bahwa peserta didik menginginkan bahan ajar yang menarik, artinya LKPD yang disediakan memiliki warna yang menarik, serta tidak membosankan.

\section{Hasil Analisis Peserta Didik}

Peserta didik kelas VIII menjadi subjek penelitian dalam uji coba LKPD berbasis $P B L$. Analisis dilakukan pada peserta didik kelas VIII SMPN 13 dan SMPN 15 Padang yang terdaftar pada semester I tahun ajaran 2015/ 2016. Karakteristik pertama yang diperoleh yaitu peserta didik berada tahap operasi formal. Peserta didik tersebut berusia pada kisaran 13-14 tahun. Berdasarkan penelitian Piaget, maka disimpulkan pada usia tersebut perkembangan kognitif yang dimiliki seorang anak telah berada pada tahap operasi formal [9]. 
Pada tahap operasi formal, anak sudah mampu melakukan penyelesaian masalah, dan bernalar dengan menggunakan hal-hal abstrak. Penggunaan benda-benda konkrit sudah tidak diperlukan lagi. Budiningsih mengemukakan bahwa ciri pokok perkembangan pada tahap ini adalah anak sudah mulai berpikir abstrak dan logis. Model berpikir ilmiah dengan kemampuan menarik kesimpulan, menafsirkan, dan mengembangkan hipotesis telah dimiliki oleh anak pada tahap ini [10].

Karakteristik peserta didik yang kedua, berdasarkan wawancara dan observasi yang dilakukan, diketahui bahwa peserta didik lebih senang belajar dengan tutor teman sebaya. Hal ini terlihat pada saat proses pembelajaran berlangsung, jika peserta didik belum mengerti dengan materi pelajaran yang diajarkan guru, maka sebagian besar peserta didik lebih suka bertanya dengan temannya. Menurut peserta didik, bertanya dengan teman yang telah mengerti dapat membantu mereka agar memahami materi yang dipelajari. Peserta didik cendrung bertanya kepada temannya, dan tidak berani bertanya langsung kepada guru.

Karaktersitik yang ketiga yaitu peserta didik kurang konsentrasi bahkan tidak fokus terhadap proses pembelajaran yang disampaikan oleh guru. Banyak peserta didik yang bercerita dengan teman sebangkunya pada saat guru menjelaskan materi pelajaran di depan kelas. Pada saat guru menegur barulah mereka memperhatikan apa yang dijelaskan guru, namun setelah beberapa menit kemudian mereka akan kembali bercerita dengan temannya. Karakteristik keempat yaitu sebagian besar peserta didik suka berkelompok ketika melakukan suatu kegiatan, misalnya berbelanja ke kantin atau pergi ke suatu tempat. Karakter ini menunjukkan bahwa peserta didik lebih suka melakukan suatu aktivitas secara bersama-sama.

Berdasarkan karakter yang ditemui, maka peneliti merasa perlu mengembangkan LKPD berbasis $P B L$ yang dapat mengakomodasi karakter yang dimiliki peserta didik pada arah yang positif dalam proses pembelajaran. LKPD berbasis $P B L$ merupakan sumber belajar yang dapat mengakomodasi karakter peserta didik yang suka berdiskusi, dan tidak fokus pada apa yang diterangkan guru pada saat proses pembelajaran. Pembelajaran dengan menggunakan LKPD berbasis $P B L$ mengajak peserta didik untuk aktif mulai dari awal proses pembelajaran. Selain itu, peserta didik juga diajarkan bagaimana langkah-langkah dalam menyelesaikan soal-soal pemecahan masalah. Jika ada beberapa peserta didik yang lebih suka belajar secara individu, LKPD berbasis $P B L$ juga akan menuntun peserta didik untuk aktif mengkonstruksi pengetahuannya secara mandiri.

\section{Hasil Analisis Kurikulum}

Analisis kurikulum dilakukan terhadap standar kompetensi (SK) dan kompetensi dasar (KD) yang tercantum dalam standar isi 2006. Analisis ini menjadi pedoman dalam melakukan pengembangan LKPD berbasis $P B L$ untuk materi matematika semester 1 kelas VIII SMP. Analisis dilakukan untuk melihat materi (SK, KD) manakah yang dapat disajikan pada LKPD berbasis $P B L$. Selain itu, analisis kurikulum dilakukan untuk mengetahui apakah materi (SK dan KD) yang ada pada kurikulum telah terurut dengan baik, serta untuk mengetahui apakah materi tersebut telah memadai 
untuk tercapainya tujuan kurikulum yaitu mengembangkan kemampuan pemecahan masalah matematis peserta didik.

Berdasarkan analisis tersebut, maka diperoleh SK yang sesuai dengan proses pembelajaran berbasis $P B L$ adalah SK 2 dan 3, yaitu memahami sistem persamaan linear dua variabel dan menggunakannya dalam pemecahan masalah, serta menggunakan Teorema Pythagoras dalam pemecahan masalah. Pada kedua SK tersebut, kemampuan minimal peserta didik yang diharapkan tercapai adalah mampu menggunakan materi (SPLDV dan Teorema Pythagoras) tersebut dalam pemecahan masalah. Ini artinya, kemampuan pemecahan masalah merupakan tujuan utama dalam proses pembelajaran. Sedangkan pada SK memahami bentuk aljabar, relasi, fungsi, dan persamaan garis lurus, tidak menekankan pada proses pemecahan masalah.

Analisis terhadap SK dan KD selanjutnya, mengindikasi agar dilakukan perubahan urutan pada kompetensi dasarnya, hal ini dilakukan untuk menyesuaikan keterkaitan antar setiap konsep. Selain itu, agar tercapainya tujuan pembelajaran yakni mengembangkan kemampuan pemecahan masalah matematis peserta didik, maka dilakukan perubahan urutan. Perubahan urutan terjadi pada kompetensi dasar untuk materi SPLDV. Hasil analisis kompetensi dasar tersebut dapat dilihat pada Tabel 2.

Tabel 2

Analisis Kompetensi Dasar

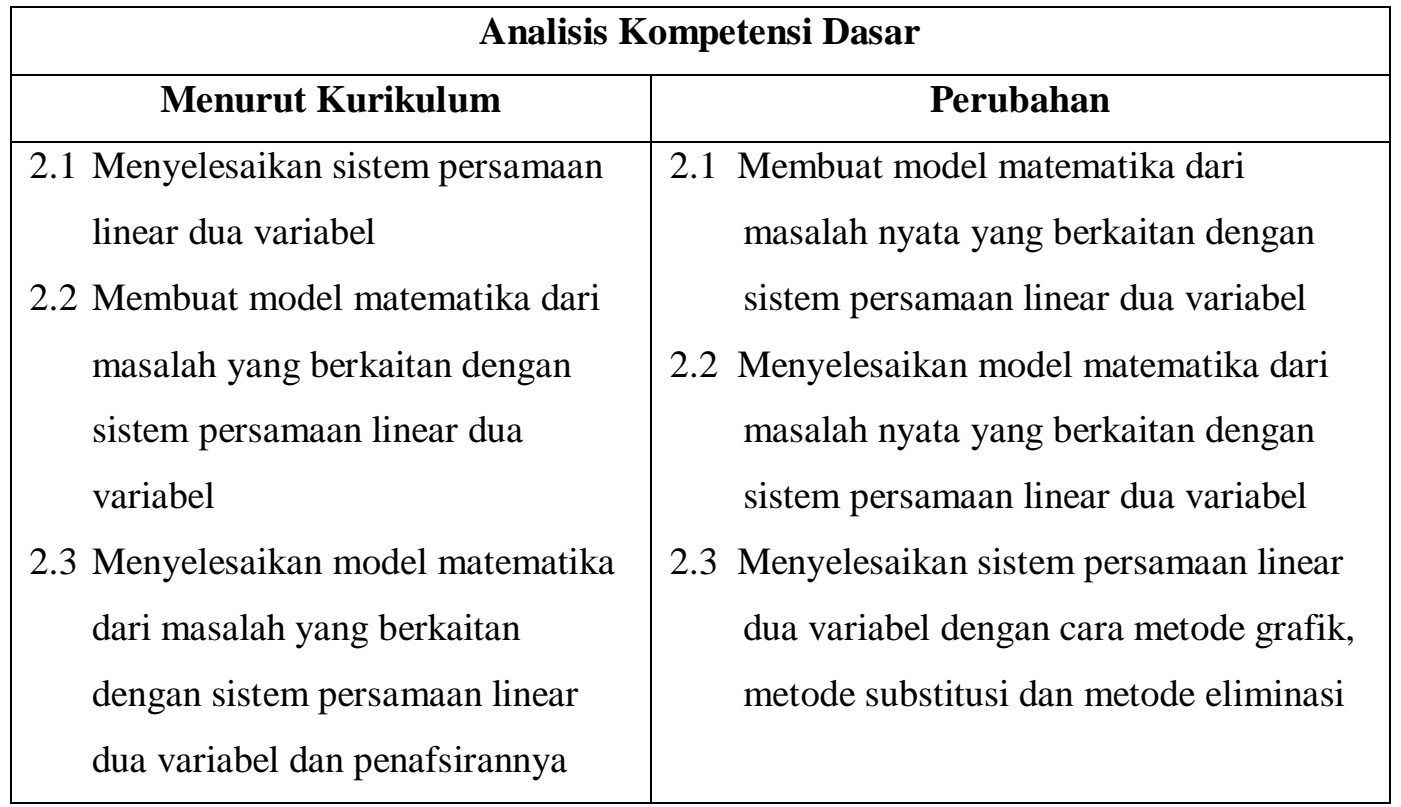

Pada Tabel 2, terlihat bahwa pada urutan KD pertama, peserta didik diharapkan dapat membuat model matematika dari masalah nyata yang berkaitan dengan SPLDV terlebih dahulu. Hal ini dilakukan agar peserta didik dapat memahami makna dari setiap model matematika yang terdapat pada SPLDV.

Model matematika yang terdapat pada SPLDV berasal dari permodelan yang berkaitan dengan keseharian peserta didik atau yang sudah dapat dipikirkan oleh peserta didik. Setelah peserta 
didik dapat membuat model matematika dari masalah nyata yang berkaitan dengan SPLDV, peserta didik diharapkan dapat menyelesaian model matematika tersebut dengan cara melakukan trial-error atau dengan cara coba-coba. Selanjutnya barulah peserta didik dibimbing untuk menyelesaikan SPLDV dengan menggunakan metode grafik, subtitusi, dan eliminasi. Melalui hal tersebut, maka pandangan peserta didik bahwa matematika adalah penerapan rumus, dan penggunaan prosedur yang kaku dapat diperbaiki melalui kegiatan menemukan solusi dari permasalahan yang diberikan melalui cara trial and error.

\section{Hasil Analisis Konsep}

Analisis konsep bertujuan untuk menentukan isi dan materi yang dibutuhkan dalam mengembangkan LKPD. Adapun konsep utamanya adalah memahami sistem persamaan linear dua variabel dan menggunakannya dalam pemecahan masalah, serta menggunakan teorema Pythagoras dalam pemecahan masalah. Pada pokok bahasan sistem persamaan linear dua variabel (SPLDV), dan teorema Pythagoras, seluruh materi yang terdapat pada pokok bahasan tersebut disajikan pada LKPD berbasis $P B L$.

\section{Hasil Analisis Bahan Ajar yang Telah Ada}

Bahan ajar yang digunakan guru dalam proses pembelajaran di kelas VIII SMP Negeri 13 dan SMP Negeri 15 kota Padang adalah buku paket matematika yang disusun oleh M.Cholik Adinawan, dan Sugijono untuk SMP Kelas VIII, dan Materi Ajar dan Latihan peserta didik yang diperoleh dari sekolah. Berdasarkan analisis isi buku paket, khususnya pada materi SPLDV dan teorema Pythagoras, pada setiap bab telah disajikan tujuan pembelajaran dari materi yang akan disampaikan, SK, KD, dan materi prasyarat untuk setiap bab. Selanjutnya pada setiap bab dijelaskan materi pelajaran, contoh soal, dan latihan-latihan untuk dikerjakan. Pada setiap latihan juga terdapat soal-soal bersifat pemecahan masalah. Namun demikian, sebagaimana yang telah disampaikan di latar belakang, bahwa bahan ajar tersebut tidak dapat secara optimal memfasilitasi peserta didik untuk dapat menumbuhkembangkan kemampuan pemecahan masalah matematisnya. Begitu juga dengan materi ajar yang disediakan di sekolah. Materi ajar tersebut belum dapat secara optimal untuk memfasilitasi peserta didik menumbuh-kembangkan kemampuan pemecahan masalah matematisnya. Hal ini dikarenakan soal-soal yang diberikan tidak sesuai dengan kriteria soal pemecahan masalah. Pada bahan ajar tersebut juga tidak disajikan langkah-langkah yang dapat mengajarkan peserta didik bagaimana seharusnya menyelesaikan soal-soal pemecahan masalah.

Berdasarkan hasil analisis bahan ajar yang telah ada, juga diperoleh inspirasi yang dapat diambil dan digunakan dalam merancang LKPD berbasis $P B L$, yaitu tujuan pembelajaran disampaikan pada setiap bab. Selain itu, sebagaimana yang disajikan pada buku dan materi ajar tersebut, LKPD berbasis $P B L$ juga dilengkapi dengan uji kompetensi pada setiap subbahasannya, dan uji kompetensi bab disajikan pada setiap babnya. 
Perubahan yang dilakukan jika dibandingkan dengan bahan ajar sebelumnya terjadi pada segi pendekatan pembelajaran. Jika pada bahan ajar yang ada belum secara optimal membuat peserta didik untuk aktif dalam mencari dan membangun konsep dari pelajarannya, maka pada LKPD berbasis $P B L$ yang dikembangkan, peserta didik dituntut secara total untuk aktif dalam proses pembelajaran, peserta didik akan dibimbing untuk memecahkan permasalahan yang berkaitan dengan materi pelajaran. Jika pada bahan ajar sebelumnya, materi pelajaran diberikan diawal pembelajaran dan permasalahan diberikan diakhir pembelajaran, maka pada LKPD berbasis $P B L$, permasalahan dijadikan sebagai starting point proses pembelajaran. Selain itu, peserta didik juga diajarkan langkah-langkah atau cara dalam menyelesaikan sebuah permasalahan. Pembelajaran menggunakan LKPD berbasis $P B L$ akan memberikan pembelajaran yang bermakna bagi peserta didik.

\section{KESIMPULAN}

Berdasarkan hasil analisis pendahuluan (Preliminary Research) maka diperoleh kesimpulan bahwa untuk dapat mengasah kemampuan pemecahan masalah matematis peserta didik, guru membutuhkan perangkat pembelajaran yang dapat membantu memfasilitasi peserta didik untuk menumbuh dan mengembangkan kemampuan pemecahan masalah matematisnya. Melalui LKPD yang dilandaskan atau didasarkan atas salah satu strategi atau pendekatan yang telah terbukti untuk meningkatkan kemampuan pemecahan masalah yaitu Problem Based Learning, maka diharapkan dapat membantu peserta didik mengembangkan kemampuan pemecahan masalahnya. Selain itu, peserta didik juga membutuhkan LKPD yang dapat membangkitkan semangatnya untuk belajar dalam hal ini dilihat dari segi bentuk dan isi dari LKPD berbasis $P B L$. Beberapa peserta didik juga menyatakan bahwa melalui penyajian permasalahan yang berhubungan dengan dunia nyata dapat membuat mereka antusias dalam belajar, karena pelajaran tidak hanya terpaku untuk menghapal rumus.

Berdasarkan analisis peserta didik, maka juga diperoleh kesimpulan bahwa peserta didik membutuhkan LKPD berbasis $P B L$ yang dapat mengakomodir karakteristik peserta didik seperti kecendrungan untuk belajar dengan cara tutor teman sebaya. Selain itu, berdasarkan analisis kurikulum juga diperoleh materi (SK, KD) yang sesuai dengan LKPD berbasis $P B L$, yaitu materi SPLDV dan teorema Pythagoras pada semester 1 kelas VIII SMP, selain itu dilakukan perubahan urutan pada materi SPLDV.

\section{DAFTAR PUSTAKA}

Hudojo, Herman. (2005). Pengembangan Kurikulum dan Pembelajaran Matematika. Malang: Penerbit Universitas Negeri Malang.

Permendiknas No 58 tahun 2014. (2014). Jakarta.

Trianto. (2009). Mendesain Model Pembelajaran Inovatif - Progresif. Jakarta: Kencana.

Prastowo, Andi. (2010). Panduan Kreatif Membuat Bahan Ajar Inovatif. Jogjakarta: Diva Press. 
Kunandar. (2011). Guru Profesional: Impelentasi Kurikulum Tingkat Satuan Pendidikan (KTSP) dan Sukses dalam Sertifikasi Guru. Jakarta: Rajawali Press.

Wena, Made. (2013). Strategi Pembelajaran Inovatif Kontemporer. Jakarta: Bumi Aksara.

Rusman. (2012). Model-Model Pembelajaran: Mengembangkan Profesionalisme Guru. Jakarta: Rajawali Pers.

Plomp, T and Nieveen, N. (2013). An Introduction to Educational Design Research. Enschede: Netherland Institute for Curriculum Development (SLO)

TIM MKPBM. (2001). Common Text Book; Strategi Pembelajaran Matematika Kontemporer. Bandung: Penerbit JICA-UPI.

Budiningsih. (2005). Belajar dan Pembelajaran. Jakarta: Rineka Cipta 